\title{
Analysis Of Financial Health Level On Financial Performance In Cement Companies Listed On The Indonesian Stock Exchange (Idx)
}

\author{
Dhea Zatira ${ }^{\text {) }}$ \\ dhea.zatira@umt.ac.id \\ Ria Puspitasari2) \\ ria.puspitasari@umt.ac.id
}

1)2)Universitas Muhammadiyah, Fakultas Ekonomi dan Bisnis

\begin{abstract}
ABSTRAC
This study aims to analyze the Level of Financial Soundness on Financial Performance in Cement Companies that are Go Public Listed on the Indonesia Stock Exchange (BEI). Analysis of the level of financial health using the Altman Z-Score with several ratios, namely the ratio of Working Capital to Total Assets (X1), the ratio of retained earnings to total assets (X2), the ratio of EBIT to Total Assets (X3), the ratio of stock market value to book value ofabilities (X4), the ratio of Sales to Total Assets (X5) to the dependent variable on Financial Performance (Return on Assets). The data analysis technique used in this research is the Altman Z-Score with the criteria for bankruptcy and to find its effect with the panel data regression model assisted by E-Views software. The results of the calculation and analysis of the Z-Score criteria in cement companies in Indonesia, it is known that there is no cement company whose company finances are stated in a healthy condition. One company is prone to bankruptcy (gray zone) while the rest according to the Z-Score criteria are bankrupt. Furthermore, based on the panel data regression examiner simultaneously the five independent variables on financial performance $(Y)$, while partially the working capital ratio to total assets (X1) affects financial performance (Y), the retained earnings ratio to total assets (X2) has no effect on Financial performance (Y), EBIT ratio to total assets (X3) affects financial performance (Y), stock market value ratio to book value of liabilities (X4) has no effect on financial performance (Y), Sales to Total Assets ratio (X5) affect financial performance.
\end{abstract}

Keyword: Altman Z-Score and Financial Performance 


\section{PRELIMINARY}

The more rapidly developing business world in the era of globalization requires companies to be more effective and efficient in running their businesses. In general, a company is established with the aim of obtaining optimal profit, as well as for cement companies, the current economic development can be seen from the proliferation of more equitable development, so that the need for cement is increasing from year to year. However, the many cement companies make competition even higher, so that companies that are not able to compete cannot survive. Increased raw material prices and other costs that are not balanced with the company's capital capacity are reasons that will hinder the company's operations, this in turn will have an impact on the high selling price of the product which causes the product to be difficult to sell in the market and can also cause the company experiencing financial difficulties until bankruptcy.

Financial difficulties begin when the company cannot meet the payment schedule or when cash flow projections indicate that the company will soon fail to fulfill its obligations (Brigham and Daves in Fachrudin (2008: 2)). It is necessary to know how financially sound a company is to prevent bankruptcy for the company's management, so that it can determine the next appropriate steps to take. Likewise for investors, information regarding financial health will determine whether or not an investor should invest in the company. One method to detect bankruptcy can be used the ZScore Analysis model. Altman, a financial economist, developed the Z-Score model from a multiple discriminant technique that uses several variables including several financial ratios. So that to examine the Z-Score Analysis model, financial statements from the balance sheet and profit and loss are needed.

The financial health of a company will affect the performance it will produce, according to Fahmi (2012: 2). Financial performance is a reflection of how successful the company's management is in achieving company goals, which can be seen from the various activities that have been carried out. According to Dewa and Sitohang (2015) Financial performance is used to evaluate the efficiency and effectiveness of a business. Company performance appraisal can also be done by analyzing the company's financial statements, of course, a good financial report is one that can provide returns to investors and creditors on a regular basis. Profitability ratios can be used to measure the company's performance in generating returns that can be allocated to external parties. The healthier a company, the better the company's performance.

The main data as input in this ratio analysis are the company's income statement and statement of financial position (balance sheet). With this report, a number of ratios can be determined and then this ratio can be used to assess several aspects of the company's operations (Syamsudin, in Khamida, 2012). This study will analyze company performance as measured by profitability ratios, namely return on assets and five financial ratios to detect financial health in the future using the Almant Z-Score discriminant method. The five ratios consist of the Ratio of Working Capital to Total Assets (X1), the Ratio of Retairned Earning to Total Assets (X2), the ratio of EBIT to Total Assets (X3), the Ratio of Market Value of Share to Book Value (X4) and the Ratio of Sales to Total. Assets (X5).

The research objects to be used are publicly traded cement companies listed on the Indonesia Stock Exchange (IDX), namely PT Indocement Tunggal Prakarsa Tbk, PT 
Semen Indonesia Tbk, PT Wijaya Karya Beton Tbk, PT Semen Baturaja Tbk, PT Solusi Bangun Indonesia Tbk., And PT Waskita Beton Precast Tbk.

The six companies are able to present financial reports regularly and periodically from 2016 to 2019 so that they will be used as research objects with the title "Analysis of Financial Health Levels on Financial Performance at Go Public Cement Companies Listed on the Indonesia Stock Exchange (BEI)".

\section{DISCUSSION OF RESEARCH RESULTS}

\section{A. Analysis of Financial Soundness Level and Bankruptcy Predictions}

Z-Score analysis is an analysis that can be used to determine the signs or symptoms of unhealthy company. With Z-Score analysis, management can predict how the company's prospects in the future will maintain its survival. The greater the $Z$ value, the greater the guarantee for the survival of the company and the less risk of failure. Z-Score analysis is used to predict company bankruptcy. In addition, bankruptcy analysis is useful because it can make companies anticipate what is needed (Khamidah, 2012). The bankruptcy analysis model (Z-score) from Altman et al. (1995) which has been revised in Boedi and Devi (2013) is as follows:

Information:

$\mathrm{X}_{1}=$ Rasio Working Capital to Total Assets

$\mathrm{X}_{2}=$ Rasio retained earning to total assets

$\mathrm{X}_{3}=$ Rasio EBIT to Total Assets

$\mathrm{X}_{4}=$ Rasio Market Value Of Share to Book Value of Liability

$\mathrm{X}_{5}=$ Rasio Sales to Total Assets

The criteria for bankruptcy according to Altman in Hanafi \& Abdul Halim, 2007 are as follows:

Table 1. Bankruptcy Criteria

\begin{tabular}{|c|c|c|}
\hline No. & Altman Z-Scove & Predikat \\
\hline 1 & Z $>2,90$ & Sehat \\
\hline 2 & Zi diantara $1,20-2,90$ & Rawan Bangkut (Grey Area / zone of ignorance) \\
\hline 3 & Zi $<1,20$ & Bankut \\
\hline
\end{tabular}

After calculating the respective values of $X 1, X 2, X 3, X 4$ and $X 5$ for four consecutive years, it can be seen that the average Z-Score value of cement companies in Indonesia is presented in the following table:PT Indocement Tunggal Prakarsa Tbk.

1. PT Indocement Tunggal Perkasa

Table 2. Z-Score Calculation of PT Indocement Tunggal Prakarsa Tbk

\begin{tabular}{|c|c|c|c|c|c|c|c|c|c|}
\hline \multirow{3}{*}{$\begin{array}{c}\text { RASIO } \\
\mathrm{X} 1\end{array}$} & \multirow{2}{*}{$\mathbf{z}$} & \multicolumn{8}{|c|}{ Tahun } \\
\hline & & \multicolumn{2}{|c|}{2016} & \multicolumn{2}{|c|}{2017} & \multicolumn{2}{|c|}{2018} & \multicolumn{2}{|c|}{2019} \\
\hline & 0.717 & 0.373 & 0.267 & 0.326 & 0.234 & 0.302 & 0.216 & 0.323 & 0.232 \\
\hline $\mathrm{X} 2$ & 0.847 & 0.726 & 0.615 & 0.704 & 0.596 & 0.689 & 0.584 & 0.675 & 0.572 \\
\hline $\mathrm{x} 3$ & 3.107 & 0.138 & 0.427 & 0.079 & 0.246 & 0.029 & 0.089 & 0.069 & 0.213 \\
\hline $\mathrm{x} 4$ & 0.420 & 0.457 & 0.192 & 0.427 & 0.179 & 0.403 & 0.169 & 0.066 & 0.028 \\
\hline $\mathrm{x} 5$ & 0.998 & 0.510 & 0.508 & 0.500 & 0.499 & 0.566 & 0.565 & 0.575 & 0.574 \\
\hline \multicolumn{3}{|c|}{ Nilai Z-Sscore } & 2.010 & & 1.755 & & 1.623 & & 1.619 \\
\hline \multirow{2}{*}{\multicolumn{3}{|c|}{ Rata-rata Kriteria }} & \multicolumn{7}{|c|}{$(2.010+1.755+1.623+1.619) / 4=1.752$} \\
\hline & & & \multicolumn{7}{|c|}{ (Rawan Bangkrut) } \\
\hline
\end{tabular}

(Source: Data processed, 2020) 
Based on the calculation of the average Z-Score of PT Indocement Tunggal Prakarsa Tbk in 2016-2019, it is prone to bankruptcy because the Z-score is 1.752, which means $1.20<1.752<2.9$.

2. PT Semen Indonesia Tbk.

Table 3. Z-Score Calculation of PT Semen Indonesia Tbk.

(Source: Data processed, 2020)

\begin{tabular}{|c|c|c|c|c|c|c|c|c|c|}
\hline \multirow{3}{*}{$\frac{\text { RASIO }}{\text { X1 }}$} & \multirow{3}{*}{\begin{tabular}{c|}
$\mathbf{z}$ \\
0.717
\end{tabular}} & \multicolumn{8}{|c|}{ Tahun } \\
\hline & & \multicolumn{2}{|c|}{2016} & \multicolumn{2}{|c|}{2017} & \multicolumn{2}{|c|}{2018} & \multicolumn{2}{|c|}{2019} \\
\hline & & 0.050 & 0.036 & 0.102 & 0.073 & 0.156 & 0.112 & 0.055 & 0.040 \\
\hline $\mathrm{X} 2$ & 0.847 & 0.052 & 0.044 & 0.005 & 0.004 & 0.045 & 0.038 & 0.014 & 0.012 \\
\hline $\mathrm{X3}$ & 3.107 & 0.157 & 0.489 & 0.100 & 0.311 & 0.130 & 0.402 & 0.109 & 0.339 \\
\hline $\mathrm{X} 4$ & 0.420 & 0.434 & 0.182 & 0.320 & 0.134 & 0.326 & 0.137 & 0.135 & 0.057 \\
\hline $\mathrm{x} 5$ & 0.998 & 0.591 & 0.590 & 0.568 & 0.567 & 0.604 & 0.603 & 0.506 & 0.505 \\
\hline \multicolumn{3}{|c|}{ Nilai Z-Sscore } & 1.342 & & 1.090 & & 1.292 & & 0.952 \\
\hline \multirow{2}{*}{\multicolumn{3}{|c|}{ Rata-rata Kriteria }} & \multicolumn{7}{|c|}{$(1.342+1.090+1.292+1.952) / 4=1.169$} \\
\hline & & & \multicolumn{7}{|c|}{ (Bangkrut) } \\
\hline
\end{tabular}

Based on the calculation of the average Z-Score of PT Semen Indonesia Tbk. 20162019 went bankrupt because the $Z$ value was $1.169<1.20$.

3. PT Wijaya Karya Beton Tbk.

Table 4. Z-Score Calculation of PT Wijaya Karya Beton Tbk.

(Source: Data processed, 2020)

\begin{tabular}{|c|c|c|c|c|c|c|c|c|c|}
\hline \multirow{3}{*}{\begin{tabular}{|c|} 
RASIO \\
X1 \\
\end{tabular}} & \multirow[b]{3}{*}{ 0717 } & \multicolumn{8}{|c|}{ Tahun } \\
\hline & & \multicolumn{2}{|c|}{2016} & \multicolumn{2}{|c|}{2017} & \multicolumn{2}{|c|}{2018} & \multicolumn{2}{|c|}{2019} \\
\hline & & 0.124 & 0.089 & 0.019 & 0.014 & 0.070 & 0.050 & 0.094 & 0.068 \\
\hline$x 2$ & 0.847 & 0.049 & 0.042 & 0.037 & 0.031 & 0.043 & 0.037 & 0.035 & 0.030 \\
\hline$x 3$ & 3.107 & 0.073 & 0.227 & 0.059 & 0.184 & 0.070 & 0.217 & 0.061 & 0.188 \\
\hline $\mathrm{X} 4$ & 0.420 & 0.384 & 0.161 & 0.190 & 0.080 & 0.145 & 0.061 & 0.122 & 0.051 \\
\hline $\mathrm{x} 5$ & 0.998 & 0.747 & 0.745 & 0.759 & 0.757 & 0.780 & 0.779 & 0.685 & 0.684 \\
\hline \multicolumn{3}{|c|}{ Nilai Z-Sscore } & 1.264 & & 1.066 & & 1.143 & & 1.021 \\
\hline \multirow{2}{*}{\multicolumn{3}{|c|}{ Rata-rata Kriteria }} & \multicolumn{7}{|c|}{$(1.264+1.066+1.143+1.021) / 4=1.123$} \\
\hline & & & \multicolumn{7}{|c|}{ (Bangkrut) } \\
\hline
\end{tabular}

Based on the calculation of the average Z-Score of PT Wijaya Karya Beton Tbk. 2016-2019 went bankrupt because the $Z$ value was $1.123<1.20$.

4. PT Semen Baturaja Tbk.

Table 5. Z-Score Calculation of PT Semen Baturaja Tbk.

\begin{tabular}{|c|c|c|c|c|c|c|c|c|c|}
\hline \multirow{3}{*}{\begin{tabular}{|c|} 
RASIO \\
$\mathrm{X} 1$ \\
\end{tabular}} & \multirow{2}{*}{$\mathbf{z}$} & \multicolumn{8}{|c|}{ Tahun } \\
\hline & & \multicolumn{2}{|c|}{2016} & \multicolumn{2}{|c|}{2017} & \multicolumn{2}{|c|}{2018} & \multicolumn{2}{|c|}{2019} \\
\hline & 0.717 & 0.090 & 0.064 & 0.064 & 0.046 & 0.093 & 0.067 & 0.078 & 0.056 \\
\hline $\mathrm{x} 2$ & 0.847 & 0.033 & 0.028 & 0.014 & 0.012 & 0.006 & 0.005 & 0.002 & 0.001 \\
\hline $\mathrm{x} 3$ & 3.107 & 0.234 & 0.726 & 0.118 & 0.366 & 0.139 & 0.431 & 0.135 & 0.419 \\
\hline $\mathrm{X} 4$ & 0.420 & 0.331 & 0.139 & 0.253 & 0.106 & 0.202 & 0.085 & 0.200 & 0.084 \\
\hline $\mathrm{X} 5$ & 0.998 & 0.348 & 0.347 & 0.306 & 0.305 & 0.397 & 0.396 & 0.352 & 0.351 \\
\hline \multicolumn{3}{|c|}{ Nilai Z-Sscore } & 1.304 & & 0.836 & & 0.984 & & 0.911 \\
\hline \multirow{2}{*}{\multicolumn{3}{|c|}{ Rata-rata Kriteria }} & \multicolumn{7}{|c|}{$(1.304+0.836+0.984+0.911) / 4=1.009$} \\
\hline & & & \multicolumn{7}{|c|}{ (Bangkrut) } \\
\hline
\end{tabular}

(Source: Data processed, 2020)

Based on the calculation of the average Z-Score of PT Semen Baturaja Tbk. 2016-2019 went bankrupt because the $Z$ value was $1,009<1.20$. 
5. PT Solusi Bangun Indonesia Tbk..

Table 6. Z-Score Calculation of PT Solusi Bangun Indonesia Tbk.

\begin{tabular}{|c|c|c|c|c|c|c|c|c|c|}
\hline \multirow{3}{*}{$\begin{array}{c}\text { RASIO } \\
\mathrm{X} 1\end{array}$} & \multirow{2}{*}{ Z } & \multicolumn{8}{|c|}{ Tahun } \\
\hline & & \multicolumn{2}{|c|}{2016} & \multicolumn{2}{|c|}{2017} & \multicolumn{2}{|c|}{2018} & \multicolumn{2}{|c|}{2019} \\
\hline & 0.717 & -0.145 & -0.104 & -0.126 & -0.090 & -0.383 & -0.274 & 0.012 & 0.009 \\
\hline $\mathrm{X} 2$ & 0.847 & -0.020 & -0.017 & -0.039 & -0.033 & -0.044 & -0.037 & 0.026 & 0.022 \\
\hline $\mathrm{x} 3$ & 3.107 & -0.009 & -0.027 & 0.011 & 0.035 & 0.002 & 0.007 & 0.064 & 0.198 \\
\hline $\mathrm{X} 4$ & 0.420 & 0.327 & 0.138 & 0.309 & 0.130 & 0.313 & 0.131 & 0.304 & 0.128 \\
\hline $\mathrm{x} 5$ & 0.998 & 0.479 & 0.478 & 0.478 & 0.477 & 0.056 & 0.055 & 0.565 & 0.564 \\
\hline \multicolumn{3}{|c|}{ Nilai Z-Sscore } & 0.467 & & 0.519 & & -0.117 & & 0.920 \\
\hline \multirow{2}{*}{\multicolumn{3}{|c|}{ Rata-rata Kriteria }} & \multicolumn{7}{|c|}{$\frac{1}{(0.467+0.519-0.117+0.920) / 4=0.447}$} \\
\hline & & & \multicolumn{7}{|c|}{ (Bangkrut) } \\
\hline
\end{tabular}

(Source: Data processed, 2020)

Based on the calculation of the average Z-Score P PT Solusi Bangun Indonesia Tbk. Semen Baturaja Tbk. 2016-2019 went bankrupt because the $Z$ value was 0.447 $<1.20$.

6. PT Waskita Beton Precast Tbk.

Table 7. Z-Score Calculation of PT Waskita Beton Precast Tbk.

\begin{tabular}{|c|c|c|c|c|c|c|c|c|c|}
\hline \multirow{3}{*}{$\begin{array}{c}\text { RASIO } \\
\mathrm{X} 1\end{array}$} & \multirow{2}{*}{ Z } & \multicolumn{8}{|c|}{ Tahun } \\
\hline & & \multicolumn{2}{|c|}{2016} & \multicolumn{2}{|c|}{2017} & \multicolumn{2}{|c|}{2018} & \multicolumn{2}{|c|}{2019} \\
\hline & $\begin{array}{ll}0.717 \\
\end{array}$ & 0.245 & 0.176 & 0.267 & 0.191 & 0.191 & 0.137 & 0.230 & 0.165 \\
\hline $\mathrm{x} 2$ & 0.847 & 0.053 & 0.045 & 0.095 & 0.080 & 0.116 & 0.099 & 0.125 & 0.106 \\
\hline$x 3$ & 3.107 & 0.085 & 0.263 & 0.109 & 0.338 & 0.111 & 0.344 & 0.078 & 0.243 \\
\hline $\mathrm{X} 4$ & 0.420 & 0.417 & 0.175 & 0.347 & 0.146 & 0.359 & 0.151 & 0.329 & 0.138 \\
\hline $\mathrm{x} 5$ & 0.998 & 0.343 & 0.343 & 0.476 & 0.475 & 0.526 & 0.524 & 0.462 & 0.461 \\
\hline \multicolumn{3}{|c|}{ Nilai Z-Sscore } & 1.002 & & 1.230 & & 1.255 & & 1.113 \\
\hline \multirow{2}{*}{\multicolumn{3}{|c|}{ Rata-rata Kriteria }} & \multicolumn{7}{|c|}{$(1.002+1.230+1.255+1.113) / 4=1.150$} \\
\hline & & & \multicolumn{7}{|c|}{ (Bangkrut) } \\
\hline
\end{tabular}

(Source: Data processed, 2020)

Based on the calculation of the average Z-Score P PT Waskita Beto Precast Tbk. Semen Baturaja Tbk. 2016-2019 went bankrupt because the $Z$ value was 1,150 <1.20.

Based on the results of the calculation and analysis of the Z-Score criteria in cement companies in Indonesia, it can be concluded that there is no cement company whose company finances are stated in a healthy state. One company that is prone to bankruptcy (gray zone) is PT Indocement Tunggal Prakarsa Tbk. Meanwhile, PT Semen Indonesia Tbk, PT Wijaya Karya Beton Tbk, PT Semen Baturaja Tbk, PT Solusi Bangun Indonesia Tbk., And PT Waskita Beton Precast based on the Z-Score criteria went bankrupt.

Companies that are prone to bankruptcy can avoid this by paying attention to signs of bankruptcy (Lesmana and Surjanto in Qishti, et al (2013)) such as: Sales or income that has decreased significantly, Decreased profit and / or cash flow from operations, Decreased total assets, prices The stock market has decreased significantly, the possibility of failure in the industry is high. The company is young and has significant cuts in dividends. 


\section{Panel Data Model Test \\ 1. Chow test}

Chow test is done by comparing CEM with FEM

Table 8. Chow test

\begin{tabular}{lrrr}
$\begin{array}{l}\text { RedundantFixed Effects Tes t } \\
\text { Equation: Untitled } \\
\text { Tes t aoss-s ection fixed effect }\end{array}$ & & & \\
\hline \hline Effects Test & Statistic & d.f. & Prob. \\
\hline \hline Cross-s ection F & 1.721476 & $(5,13)$ & 0.1990 \\
Cross-s ection Chis quare & 12.194052 & 5 & 0.0322 \\
\hline \hline
\end{tabular}

(Source: E-Views Data Processing, 2020)

The Chi-square cross-section probability value is $0.0322<0.05$, meaning that FEM is more suitable for use in this model. Then the Haussman test must then be carried out.

\section{Haussman test}

Conducted if the results of the Chow test, the FEM model are more suitable. Hussman test is done by comparing FEM with REM.

\section{Table 9. Haussman Test}

Correlated Random Effects - Hausman Test
Equation: Untitled
Test cross-section random effects
\begin{tabular}{lrrr}
\hline Test Summary & Chi-Sq. Statistic & Chi-Sq. d.f. & Prob. \\
\hline \hline Cross-section random & 8.607379 & 5 & 0.1258 \\
\hline \hline
\end{tabular}

(Source: E-Views Data Processing, 2020)

Based on table 9, the Chi-square cross-section probability value $0.1258>0.05$ means that the model that is more suitable for use in this test is the Random Effect Model, then the Multiple Langrange test must be carried out.

\section{Multiple Langrange Test}

The LM test is used to compare the Common Effect Model with the Random Effect Model.

Table 10. Multiple Langrange Test

\begin{tabular}{|c|c|c|c|}
\hline \multicolumn{4}{|c|}{$\begin{array}{l}\text { Lagrange multiplier (LM) test for panel data } \\
\text { Date: 09/04/20 Time: } 23: 09 \\
\text { Sample: } 20162019 \\
\text { Total panel observations: } 24 \\
\text { Probability in () }\end{array}$} \\
\hline $\begin{array}{l}\text { Null (no rand. effed) } \\
\text { Alternative }\end{array}$ & $\begin{array}{l}\text { Cross-section } \\
\text { One-sided }\end{array}$ & $\begin{array}{l}\text { Period } \\
\text { One-sided }\end{array}$ & Both \\
\hline Honda & $\begin{array}{c}-1.372459 \\
(0.9150)\end{array}$ & $\begin{array}{l}0.678727 \\
(0.2487)\end{array}$ & $\begin{array}{c}-0.490543 \\
(0.6881)\end{array}$ \\
\hline
\end{tabular}

(Source: E-Views Data Processing, 2020) 
Based on table 10, it is known that the Prob Breusch Pagan value is $0.9150>$ 0.05 , which means that the model that is more suitable for use in this study is the Common Effect Model. The Common Effect model can be seen in the table below.

Table 11. Common Effect Model

\begin{tabular}{|c|c|c|c|c|}
\hline \multicolumn{5}{|c|}{$\begin{array}{l}\text { Dependent Variable: ROA } \\
\text { Method: Panel Least Squares } \\
\text { Date: 09/04/20 Time: } 23: 43 \\
\text { Sample: } 20162019 \\
\text { Periods included: } 4 \\
\text { Cross-sections included: } 6 \\
\text { Total panel (balanced) observations: } 24\end{array}$} \\
\hline Variable & Coefficient & Std. Error & t-Statistic & Prob. \\
\hline $\mathrm{C}$ & -0.091070 & 0.024661 & -3.692947 & 0.0017 \\
\hline $\mathrm{X} 1$ & 0.108471 & 0.038027 & 2.852473 & 0.0106 \\
\hline $\mathrm{X} 2$ & 0.017599 & 0.022448 & 0.783987 & 0.4432 \\
\hline $\mathrm{X} 3$ & 0.359517 & 0.085984 & 4.181193 & 0.0006 \\
\hline $\mathrm{X} 4$ & 0.053423 & 0.030834 & 1.732592 & 0.1003 \\
\hline $\mathrm{X} 5$ & 0.135743 & 0.032281 & 4.205017 & 0.0005 \\
\hline R-squared & 0.832221 & \multicolumn{2}{|c|}{ Mean dependent var } & 0.042306 \\
\hline Adjusted R-squared & 0.785616 & \multicolumn{2}{|c|}{ S.D. dependent var } & 0.038839 \\
\hline S.E. of regression & 0.017983 & \multirow{2}{*}{\multicolumn{2}{|c|}{$\begin{array}{l}\text { Akaike info criterion } \\
\text { Schwarz criterion }\end{array}$}} & -4.986465 \\
\hline Sum squared resid & 0.005821 & & & -4.691952 \\
\hline Log likelihood & 65.83758 & \multirow{2}{*}{\multicolumn{2}{|c|}{$\begin{array}{l}\text { Hannan-Quinn criter. } \\
\text { Durbin-Watson stat }\end{array}$}} & -4.908331 \\
\hline F-statistic & 17.85681 & & & 2.423335 \\
\hline Prob(F-statistic) & 0.000002 & \multicolumn{2}{|c|}{ Durbin-Watson stat } & \\
\hline
\end{tabular}

(Source: E-Views Data Processing, 2020)

Because the Common Effect Model is more suitable for use in this study, this research needs to test the classical assumptions.

\section{Classical Assumption Test}

\section{Normality Test}

Figure 1. Normality Test

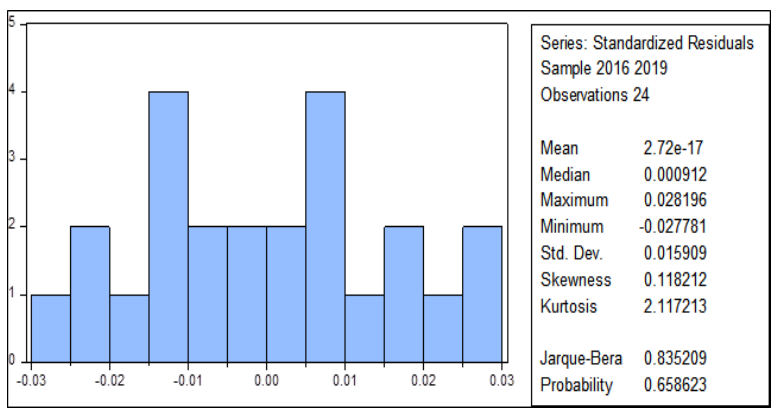

(Source: E-Views Data Processing, 2020)

Based on Figure 1, it is known that the Jarque-Bera value is 0.835209 and the probability is 0.658623 . Jarque-Bera value of $0.835209>0.05$ means that the residuals are normally distributed. 


\section{Multicollinearity Test}

Table 12. Multicollinearity Test

\begin{tabular}{|cccccc|}
\hline & $\mathrm{X} 1$ & $\mathrm{X} 2$ & $\mathrm{X} 3$ & $\mathrm{X} 4$ & $\mathrm{X} 5$ \\
$\mathrm{X} 1$ & 1 & $0.69500934 \ldots$ & $0.38948123 \ldots$ & $0.257264477 \ldots$ & $-0.0805318 \ldots$ \\
$\mathrm{X} 2$ & $0.69500934 \ldots$ & 1 & $-0.0108825 \ldots$ & $0.17578664 \ldots$ & $0.04436266 \ldots$ \\
$\mathrm{X} 3$ & $0.38948123 \ldots$ & $-0.0108825 \ldots$ & 1 & $0.038677747 \ldots$ & $-0.3605221 \ldots$ \\
X4 & $0.25726447 \ldots$ & $0.17578664 \ldots$ & $0.03867747 \ldots$ & 1 & $-0.2308116 \ldots$ \\
$\mathrm{X} 5$ & $-0.0805318 \ldots$ & $0.04436266 \ldots$ & $-0.3605221 \ldots$ & $-0.2308116 \ldots$ & 1 \\
\hline
\end{tabular}

(Source: E-Views Data Processing, 2020)

Based on table 12 it can be seen that there is no variable whose value is more than 0.8 , so it can be concluded that there is no multicollinearity in this regression model.

\section{Panel Data Regression Test}

To determine the functional relationship between variables $\mathrm{X} 1, \mathrm{X} 2, \mathrm{X} 3, \mathrm{X} 4, \mathrm{X} 5$ and variable $Y$ (Return on Assets), multiple linear regression analysis is used.

Table 13. multiple linear regression Analysis

\begin{tabular}{crr}
\hline \hline Variable & Coefficient & Std. Error \\
\hline \hline C & -0.091070 & 0.024661 \\
X1 & 0.108471 & 0.038027 \\
X2 & 0.017599 & 0.022448 \\
X3 & 0.359517 & 0.085984 \\
X4 & 0.053423 & 0.030834 \\
X5 & 0.135743 & 0.032281 \\
\hline \hline
\end{tabular}

(Source: E-Views Data Processing, 2020)

Based on table 13, the equation for multiple linear regression analysis is as follows:

$Y=-0,091070+0,108471+0.017599+0,359517$

$+0,053423+0,135743+\varepsilon$

The multiple linear equation above has the following meanings:

- If $X 1, X 2, X 3, X 4$ and $X 5=0$, then $Y$ is equal to the constant value, namely -0.09107

- If $X 1=1, X 2, X 3, X 4$ and $X 5=0$, then every 1 unit addition of $X 1$ will add $Y$ by 0.0108471 .

- If $\mathrm{X} 2=1, \mathrm{X} 1, \mathrm{X} 3, \mathrm{X} 4$ and $\mathrm{X} 5=0$, then every 1 unit addition of $\mathrm{X} 2$ will add $\mathrm{Y}$ by 0.017599 .

- If $\mathrm{X} 3=1, \mathrm{X} 1, \mathrm{X} 2, \mathrm{X} 4$ and $\mathrm{X} 5=0$, then every 1 unit addition of $\mathrm{X} 3$ will add $\mathrm{Y}$ by 0.359517 .

- If $X 4=1, X 1, X 2, X 3$ and $X 5=0$, then each addition of 1 unit of $X 4$ will add to the $Y$ value of 0.053423

- If $X 5=1, X 1, X 2, X 3$ and $X 4=0$, then each addition of 1 unit of $X 5$ will add to the $Y$ value by 0.135743 .

\section{Hypothesis Testing}

\section{F-test}

The $\mathrm{F}$ test is intended to test whether all the independent variables contained in the model have a joint influence on the dependent variable. 


\begin{tabular}{lr}
\multicolumn{2}{c}{ Table 14. F test } \\
F-statistic & 17.85681 \\
Prob(F-statistic) & 0.000002
\end{tabular}

(Source: E-Views Data Processing, 2020)

Table 14 shows that the value of the F-statistic or F-count is 17.85681, while the Ftable with a level of $\alpha=5 \%$, df1 $(k-1)=4$, df2 $(\mathrm{nk})=19$. Obtained an F-table value of 2.90 means that F-count $17.85681>$ F-table 2.90 and the probability value F-statistic $0.000002<0.05$, then $\mathrm{H} 1$ is accepted, so it can be concluded that X1, X2, X3, X4 and X5 together have an effect on $\mathrm{Y}$.

\section{2. $\mathbf{R}^{2}$ test}

Testing the coefficient of determination (R2) aims to measure how far the model's ability to explain the variation of dependent variables. The value of the coefficient of determination is between zero and one. If the coefficient of determination of a model is close to one, it means that the independent variables can provide almost all the information needed to explain variations in the dependent variable (Arry, 2017).

\begin{tabular}{ll}
\multicolumn{2}{c}{ Tabel 15. Uji $\mathbf{R}^{\mathbf{2}}$} \\
R-squared & 0.832221 \\
Adjusted R-squared & 0.785616
\end{tabular}

(Source: E-Views Data Processing, 2020)

Table 15 menunjukkan bahwa nilai Adjusted R-squared sebesar 0,785616, artinya variasi perubahan naik turunya $\mathrm{Y}$ dapat dijelaskan oleh $\mathrm{X} 1, \mathrm{X} 2, \mathrm{X} 3, \mathrm{X} 4$ dan X5 sebesar $78,5616 \%$ sementara sisanya $21,4384 \%$ dijelaskan oleh variable-variabel lain yang tidak diteliti dalam penelitian ini.

\section{The t-test}

To show how far the influence of one explanatory or independent variable is individually in explaining the variation of the dependent variable, partial testing is required (Gozali, 2016). Partial test is a test that measures the magnitude of the influence of each independent variable, namely the variables EPS, PBV, ROA, DER and GPM on the dependent variable, namely the Stock Price.

\section{Table 16. $t$ - Test}

\begin{tabular}{crc}
\hline \hline Variable & t-Statistic & Prob. \\
\hline \hline C & -3.692947 & 0.0017 \\
X1 & 2.852473 & 0.0106 \\
X2 & 0.783987 & 0.4432 \\
X3 & 4.181193 & 0.0006 \\
X4 & 1.732592 & 0.1003 \\
X5 & 4.205017 & 0.0005 \\
\hline \hline
\end{tabular}

(Source: E-Views Data Processing, 2020)

a. $t$ - test (partial) Hypothesis 1: Working Capital to Total Assets (X1) on Financial Performance (Y).

The $t$-statistic or $t$-count $\mathrm{X} 1$ value is 2.852473 , while the $t$-table value with a level of $a=5 \%, d f(n-k)=19$, the $t$-table value is 2.093. Thus, $t$ statistic $2.852473>t$-table 2.093 
and a probability value of $0.0106<0.05$, then $\mathrm{H} 1$ is rejected so that it can be concluded that the hypothesis of the independent variable $\mathrm{X} 1$ has a positive and significant effect on the dependent variable, namely Financial Performance (Y) of the Cement company listed on the Indonesia Stock Exchange for the period 2016-2019.

The higher the ratio of working capital to total assets means that the greater the amount of capital used to spend on assets comes from capital than from debt. Companies that have a small interest expense, then the company's net profit will be even greater. The amount of net profit indicates that the company has a good financial performance because it is able to manage any capital given by investors to become profits that can be distributed to them.

\section{b. $t$ - Test (partial) Hypothesis 2: Ratio of Retained Earning to Total Assets (X2) to Financial Performance (Y).}

The $\mathrm{t}$-statistic or $\mathrm{t}$-value $\mathrm{X} 2$ is 0.783987 , while the $\mathrm{t}$-table value with a level of $\mathrm{a}=$ $5 \%, \mathrm{df}(\mathrm{n}-\mathrm{k})=19$, the $\mathrm{t}$-table value is 2.093 . Thus $\mathrm{t}$ statistic $0.783987<\mathrm{t}$-table 2.093 and probability value $0.4432>0.05$, then $\mathrm{H} 1$ is accepted so that it can be concluded that the hypothesis of the independent variable X2 has no effect on the dependent variable, namely Financial Performance $(Y)$ of the cement companies listed on the Stock Exchange. Indonesian Securities for the period 2016-2019.

The higher this ratio, the more retained earnings are used to spend the required assets. Retained earnings is a condition in which investors give up some of the profits that should be received but are reinvested in the company with the aim of being able to provide benefits in the future. The greater the retained earnings, the greater the financial burden to be borne by the company, if the company does not manage retained earnings properly, the sacrifices made by investors will not have an effect on the increase in the expected rate of profit. In other words, retained earnings will not affect the company's financial performance

\section{c. $t$ - test (partial) Hypothesis 3: Ratio of EBIT to Total Assets (X3) to financial performance $(\mathrm{Y})$}

The $t$-statistic value or $t$-count $X 3$ is 4.181193 , while the $t$-table value with a level of $\mathrm{a}=5 \%, \mathrm{df}(\mathrm{n}-\mathrm{k})=19$, the obtained $\mathrm{t}$-table value is 2.093 . Thus, $\mathrm{t}$ statistic $4.181193>$ $\mathrm{t}$-table 2.093 and a probability value of $0.0006<0.05$, then $\mathrm{H} 1$ is rejected, so it can be concluded that the independent variable hypothesis X3 has a positive and significant effect on the dependent variable, namely Financial Performance (Y) of listed cement companies. on the Indonesia Stock Exchange for the period 2016-2019.

The higher this ratio, it means that the total assets owned by the company are able to generate bigger profits before debt and taxes. This can happen if the company's management is able to properly manage assets, especially cash, accounts receivable and inventories. So that the higher the ratio of earnings before interest and taxes to total assets, the higher the company's financial performance.

\section{d. $t$ - test (partial) Hypothesis 4: Ratio of Market Value of Share to Book Value of Liability (X4) to Financial Performance (Y).}

The $t$-statistic or $t$-count $X 4$ value is 1.732592 , while the $t$-table value with a level of $\mathrm{a}=5 \%, \mathrm{df}(\mathrm{n}-\mathrm{k})=19$, the $\mathrm{t}$-table value is 2.093 . Thus $\mathrm{t}$ statistic $1.732592<\mathrm{t}$-table 2.093 and probability value $0.1003>0.05$, then $\mathrm{H} 1$ is accepted so that it can be 
concluded that the independent variable hypothesis $\mathrm{X} 4$ has no effect on the dependent variable, namely Financial Performance $(Y)$ of the cement companies listed in Indonesia Stock Exchange 2016-2019 period.

The higher this ratio, it means that the amount of capital owned by the company is greater than the debt it has. The source of capital must be adjusted to the needs and prospects of the company, because the source of capital originating from debt will provide an interest expense that must be borne by the company, while the source of capital from its own capital (share capital) will provide a burden of return to investors which is only done if the company is experiencing a profit. If the asset management is carried out properly, the company will be able to pay the capital burden it has, so that sourced from debt or own capital, the source of capital it gets will not affect the company's financial performance in generating profit.

\section{e. T test (partial) Hypothesis 5 Ratio of Sales to Total Assets (X5) to Financial Performance (Y)}

The $t$-statistic value or $\mathrm{t}$-count $\mathrm{X} 5$ is 4.205017 , while the $\mathrm{t}$-table value with a level of $a=5 \%, d f(n-k)=19$, the $t$-table value is 2.093 . Thus, $t$ statistic $4.205017>t$-table 2.093 and a probability value of $0.0006<0.05$, then $\mathrm{H} 1$ is rejected, so it can be concluded that the hypothesis of the independent variable X5 has a positive and significant effect on the dependent variable, namely the Financial Performance (Y) of the Cement company listed on the Indonesia Stock Exchange for the period 2016-2019.

This ratio illustrates the number of assets that are capable of generating a sales level for the company, so the higher this ratio indicates the higher the level of sales resulting from the processing of its assets. The higher the level of sales which is not followed by high expenses to be paid will increase net income. resulting from. So that the higher the ratio of sales to total assets, the higher the financial performance in generating profits.

\section{CONCLUSION}

Based on the analysis that has been done, there are several conclusions in this study.

a. Based on the results of the calculation and analysis of the Z-Score criteria in cement companies in Indonesia, it can be concluded that there is no cement company whose company finances are in a healthy state. One company that is prone to bankruptcy (gray zone) is PT Indocement Tunggal Prakarsa Tbk. Meanwhile, PT Semen Indonesia Tbk, PT Wijaya Karya Beton Tbk, PT Semen Baturaja Tbk, PT Solusi Bangun Indonesia Tbk., And PT Waskita Beton Precast based on the Z-Score criteria went bankrupt.

b. Working Capital to Total Assets Ratio, retained earnings to total assets ratio, EBIT to Total Assets Ratio, Market Value of Share to Book Value of Liability Ratio and Sales to Total Assets Ratio simultaneously affect the financial performance of cement companies listed on the IDX for the 2014 period -2019.

c. The working capital to total assets ratio affects the financial performance of cement companies listed on the IDX for the 2014-2019 period 
d. The ratio of retained earning to total assets has no effect on the financial performance of cement companies listed on the IDX for the 2014-2019 period

e. The EBIT to Total Assets ratio has an effect on the Financial Performance of Cement Companies listed on the IDX for the 2014-2019 Period

f. The Market Value of Share to Book Value of Liability ratio has an effect on the financial performance of cement companies listed on the IDX for the 2014-2019 period

g. The ratio of Sales to Total Assets affects the financial performance of cement companies listed on the IDX for the 2014-2019 period.

\section{BIBLIOGRAPHY}

Boedi Soelistijono dan Devi Tiara (2013). Analisis Prediksi Kebangkrutan Perusahaan Telekomunikasi Yang Terdaftar Di Bursa Efek Indonesia Dengan Model Altman. Revisi Jurnal Manajemen dan Akuntansi (JUMA) APRIL 2013, VOLUME 14 NOMOR 1

Dewa, A. P., \& Sitohang, S. (2015). Analisis Kinerja Keuangan Pt Indofood Sukses Makmur Tbk Di Bursa Efek Indonesia. Jurnal Ilmu dan Riset Manajemen.

Eksandy, Arry (2017). Pengaruh Ukuran Perusahaan, Solvabilitas, Profitabilitas dan Komite Audit Terhadap Audit Delay (Pada Perusahaan Properti dan Real Estate yang Terdaftar di Bursa Efek Indonesia Pada Tahun 2012-2015). Competitive Jurnal Akuntansi dan Keuangan, Vol.1, No.2.

Fahmi, I. (2012). Analisis Kinerja Keuangan. Bandung: Alfabeta.

Fachrudin, Khaira Amalia. (2008). Kesulitan Keungan Perusahaan dan Pesonal. Medan: Usu Press

Hanafi, M. M., \& Abdul Halim. (2007). Analisis Laporan Keuangan (tujuh). UUPMPP YKPN.

http:/ / www.idx.co.id

http:/ / www.indocement.co.id/v5/id/

https://www.sahamok.com/

https://semenbaturaja.co.id/

https://solusibangunindonesia.com/

https://www.wika.co.id/id/pages/pt-wika-beton

http://web.waskitaprecast.co.id/

Khamidah, F. N. (2012). Analisis Tingkat Kesehatan Keuangan Pada Perusahaan Semen Go Public Di Bursa Efek Indonesia. Among Makarti, 5, 55-75. http://jurnal.stieama.ac.id/index.php/ama/article/view/67

Qisthi, dkk (2013) Analisis X-Score (Model Zmijewski) Untuk Memprediksi Gejala Kebangkrutan Perusahaan (Pada Industri Otomotif dan Komponennya yang Terdaftar di BEI Periode 2009-2011) Jurnal Administrasi Bisnis (JAB)|Vol. 1 No. 2 April 2013| administrasibisnis.studentjournal.ub.ac.id 